\title{
The Effect of Music Therapy on Cognitive Functions and Adaptation in Alzheimer's Patients
}

\author{
Büşra Kayaaslan ${ }^{1}$ and Neslihan Lok ${ }^{2 *}$ \\ ${ }^{1}$ Health Sciences Institute, Selcuk University, Turkey \\ ${ }^{2}$ Department of Psychiatric Nursing, Selcuk University, Turkey
}

*Corresponding author: Dr. Neslihan Lok, Faculty, Department of Psychiatric Nursing, Selcuk University, Turkey

\begin{abstract}
With the increasing life expectancy in the world, chronic diseases are seen in elderly individuals. There is currently no treatment that can prevent, stop or cure Alzheimer's disease, one of these chronic diseases, or slow down neurodegeneration in AD. The treatments used are symptomatic treatments to slow down the course of the disease. Since the 1960s, psychosocial interventions have been used in addition to medications in the treatment of $A D$ and its use has increased after the 2000s. One of the psychosocial interventions to be applied in AD is Music Therapy. It is emphasized that Music Therapy is a promising intervention especially for $A D$ and it should be started as early as possible. It is important that nurses use Music Therapy, which is one of the non-pharmacological methods, in patients with Alzheimer's disease, in order to strengthen the coping mechanisms of the patients and increase the communication, cognitive functions and adaptation levels of the individuals with the environment. In this article, information about the effectiveness of music therapy in Alzheimer's patients will be given.
\end{abstract}

\section{Keywords}

Alzheimer's disease, Psychosocial interventions, Music therapy

\section{Introduction}

With the increasing life expectancy in the world, chronic diseases are seen in elderly individuals. It is very difficult to diagnose Alzheimer's Disease (AD) during the initial period. In addition, it is very difficult to determine the actual frequency as the attitudes towards dementia are different in different societies. According to the Alzheimer's Association [1] report, the incidence of $A D$ in individuals over 65 years is $10 \%$, this rate is
$16 \%$ in the $65-74$ age range, $44 \%$ in the $75-84$ age range, and the incidence of $A D$ in the population aged 85 and over is reported as $37 \%$ (Alzheimer's Association) [1]. It increases rapidly due to the increase in the average life. $A D$ is among the most common dementia syndromes in terms of frequency and constitutes $60-80 \%$ of dementia $[1,2]$.

In Turkey, it made in 2008, "Turkish Alzheimer's Prevalence Study (TAPS)" AH prevalence of over 70 years in the study was $16 \%$. When this ratio is applied to our country's demographic structure it is thought to be around 300-350 thousand Alzheimer's patients in Turkey [3].

$A D$ is a disorder characterized by various neuropsychiatric behavioral disorders with cognitive decline and causes impairment in daily life activities [4]. AD can develop irreversibly in any period of life (especially in old age). The first and severely damaged cognitive domain is close memory. As the disease progresses, close memory loss is accompanied by impairments in language-related functions (difficulty in finding words, paraphasia, etc.), loss of place-time-person orientation, loss of executive functions, visual spatial abilities, and behavior disorders $[1,2,5,6]$. Although loss of other cognitive domains becomes apparent over time, close memory loss is always in the foreground. As the disease progresses, distant memory also loses and the first learned is lost last. Behavioral symptoms such as agitation, depression, delusions and hallucinations may occur in the mild and moderate stages of the disease, but may occur at any time during the course of the disease 
$[2,7]$.

Currently, there is no treatment that can prevent, stop or cure $A D$, or slow down neurodegeneration in AD. The treatments used are symptomatic treatments to slow down the course of the disease [8]. It is emphasized that non-pharmacological methods should be preferred for behavioral disorders which are frequently seen except cognitive deficits and which should be included in the treatment process [9]. In particular, individuals cannot adapt to the newly developing problems as a result of different regions of the brain being affected during the transition between phases and cannot cope with the current situation. Therefore, their harmony deteriorates. Early diagnosis of $A D$ and knowing in which areas the adjustment of the individual is impaired is very important in nursing care. Nurses provide care to individuals with Alzheimer's disease in the community, in hospitals and in long-term care institutions [10]. The aim of the nurse while providing care to patients; to help the individual adapt to the changes that occur during health and illness. The main objectives of the psychiatric nurse in the care of $\mathrm{AH}$ are; Preservation of functionality by increasing the cognitive functions of the patient, reducing the disability, regulation of the environment and relationships to maintain stability, compensating losses to restore harmony caused by the disease, providing the therapeutic environment that will preserve the individuality of the patient and maintain the quality of life [9].

Medical treatment is frequently preferred in $A D$. However, medical treatments are often not sufficient to improve individual's cognitive functions and to regain adherence to the disease process. Since the transition between stages is rapid in $A D$, the aim in treatment should be to reduce the transition time between stages $[11,12]$. For this purpose, psychosocial interventions have started to be used in the treatment of $A D$ in addition to medications since the 1960s and its use has increased after the 2000s. One of the psychosocial interventions to be applied in AD is Music Therapy.

The treatment with music dates back to the history of medicine [13]. Music therapy; It is an area of expertise that uses music and music activities to meet the physical, psychological, social and mental needs of individuals [14]. MT is known to be one of the oldest treatment methods and used to treat diseases in different cultures [13]. Physiological effects of music therapy; psychophysiological stress, pain, anxiety and isolation is reduced by creating a change in behavior and changing mood [15]. In MT, music elements such as rhythm, melody and harmony are used for therapeutic purposes. In the researches, music positively affects the hormones such as serotonin, dopamine, adrenaline and testosterone, which are effective in the formation of mental illnesses and regulate our emotional state; it has been observed that it regulates physiological functions such as blood pressure and respiratory rhythm and regulates brain oxygenation and blood supply [13].

MT is said to be a good and useful method for longterm administration of non-pharmacological AD. Many articles have shown that MT can reduce cognitive retardation in autobiographical and episodic memories, psychomotor speed, executive function domains, and global cognition [15]. It is emphasized that MT is a promising intervention especially for $A D$ and it should be started as early as possible [16].

Level of compliance; individual's ability to respond positively to stimuli [17]. As human life is in constant change, harmony is essential for a happy life in every generation. Especially the elderly population is one of the groups that need adaptation process. Since aging is a process that requires adaptation to the critical conditions of life such as physical and cognitive disabilities, separations, losses and the end of life, adaptation is considered important in this age group [18].

According to Flood [19] if individuals cannot adapt to the physiological and functional changes that occur due to years, problematic results arise. Individuals develop coping mechanisms to adapt. If they use these mechanisms, they reach a higher level of adaptation than individuals who do not develop coping mechanisms or those who do not often use them. According to Roy, one of the nurses theorists; The aim of the study is to help the individual to behave harmoniously in four harmony domains (physiological requirements, self concept domain, role function domain, interdependency domain) in health and disease states. The nurse first identifies the individual's behaviors and the stimuli that cause these behaviors and affects compliance, and plans, implements and evaluates the interventions that may have an impact on the stimuli [20]. As a result of the decline in basic cognitive functions such as attention, perception, memory, and executive functions in Alzheimer's patients, it causes problems in individual's communication with their environment and makes it difficult for individuals to adapt [18]. The main goal of nursing interventions in Alzheimer's patients should be to strengthen the coping mechanisms of the individual in order to fight the stimuli. If the individual is able to cope with stimuli, the level of adaptation increases and their behavior may change from a non-compliant response to a compatible response [20]. In a study, it was observed that Music Therapy increased the level of harmony by increasing communication with the individual's environment [21]. Therefore, it is important for nurses to use Music Therapy, which is one of the non-pharmacological methods, in Alzheimer's patients in order to strengthen the coping mechanisms of the patients and to increase the communication levels of the individuals with their environment and to increase their compliance levels.

\section{Use of Music Therapy in Some Studies}

Music Therapy has a positive effect on the problems 
of Alzheimer's patients. When the literature on music therapy was examined, this study was planned due to the fact that the researches on the subject gained weight in the international arena and because of the lack of studies in the national field. When the national and international literature on the subject is examined; Guetin, et al. [22] studied 30 patients with mild to moderate Alzheimer's disease in a randomized controlled (single-blind) study. The experimental group (15 individuals) was played three days a week for two hours with selected individuals. In the control group (15 individuals) reading sessions were performed. Measurements were performed with Hamilton depression scale and geriatric depression scale at $0,1,4,8,16$ and 24 weeks. Improvements were observed in the experimental group at 16 and 24 weeks. There was a decrease in the symptoms of anxiety and depression. The music therapy effect was maintained for 8 weeks and it was found that individuals felt well during and after the application and they were also successful in preserving and transferring the information in short-term memory to long-term memory.

Raglio, et al. [23] studied 59 individuals with moderate and advanced Alzheimer type dementia in the control group experimental study. Music therapy group consisted of 29 people and control group consisted of 30 people. During the 20 weeks of music therapy sessions, the music therapy group was heard by the patients in certain tones and then asked to imitate the sound the patient was listening to with a percussion instrument. No intervention was performed in the control group. They used mini mental test and neuropsychiatry inventory as a measurement tool in their study. Music therapy group; delusions, agitation, anxiety, apathy, irritability, abnormal motor activity and sleep disorders were found to be reduced. After the music therapy session, it was observed that the patients had a more calm evening and night, and the caregivers were more comfortable, calm and pleasant. There was an increase in empathic relationship and empathic approach levels and an improvement in cognitive functions in the Music Therapy group.

Han, et al. [24] conducted a semi-experimental study with 50 patients with mild stage Alzheimer's disease. These patients were divided into 25 experimental groups and 25 control groups. In the study, they selected the songs together with the patients, and then selected a representative from them to make them sing the songs to the group. The same songs were played at each session and patients were encouraged to accompany. Music therapy was administered 16 sessions twice a week for a total of eight weeks. All sessions lasted 50 minutes. The measurement tools used were mini mental test, Beckness scale and geriatric depression scale. Music There was a decrease in depression and anxiety levels after therapy. Music program was applied to the patients in the first stage and social and emotional adjustment of the patients increased and melatonin hormone in- creased and relaxation, relaxation and happiness levels increased. It was observed that cognitive functions of Music Therapy group improved compared to before. Suzuki, et al. [25] conducted by quasi-experimental study Music Therapy group 10, control group was conducted with a total of 10 people, including 20 mid-stage Alzheimer's patients. Music therapy was applied for 8 weeks for a total of 26 sessions and 50 minutes. Mini mental test and neuropsychiatry inventory were used as measurement tools. Patient's cognitive functions improved. Agitation, anxiety, apathy and irritability decreased and behavioral symptoms improved. It has been reported that music therapy reduces the wandering behavior in patients and the care burden in caregivers.

Svansdottir, et al. [26] conducted a case-control study with 76 middle and advanced Alzheimer's patients, including 38 in the Music Therapy group and 38 in the control group. Music Therapy group; Music therapy sessions were held in different positions for 50 minutes, four days a week for six weeks. No intervention was made to the control group. Alzheimer's disease assessment scale and mini-mental test were used for the measurement. In the experimental group, there was a decrease in the levels of aggression and anxiety at the end of music therapy. During and after the application, it was found that individuals felt good and were successful in preserving and transferring information in shortterm memory to long-term memory.

In their study by Kydd, et al. [21], they examined the effectiveness of Music Therapy in a patient who showed antisocial relationships in the institution and who left the room only for meals. Music Therapy sessions held by the Music Therapist in the institution are held in the general hall areas of each part of the house, usually near the piano. The patient, who heard the music sessions in his own room and attended the sessions afterwards, was first evaluated in the music therapy group he was interested in. Weekly themes have been selected and the Music Therapist has used music to promote recall, exercise or movement and socialization and provide opportunities for cognitive stimulation. The patient was reluctant to participate in some aspects of the session, such as playing percussion instruments, recognizing others and singing. Music The therapist has decided to offer individual sessions for a period of time to draw attention to the patient individually and make a recording of his favorite music. The patient started attending individual music therapy sessions once a week for half an hour, and it took several weeks for her to stay until the end of the session. The first two months, she attended individual sessions, but also left the room when she could hear the piano and joined the regular music therapy group. The patient's participation in the group setting continued to improve over time. Most of these observations took place within eight months, but the time of group work included writing this case study. As a result of the study, it was observed that the 
patient who left his room only at meal time and showed antisocial symptoms increased his communication and adjustment level with other individuals and went out of his room more frequently. It was also observed that the patient, who did not meet with his family, contacted his son and started to see his family and participated in trips he had previously refused. It was stated by the staff to be more than pleasant, happy and social.

\section{Conclusion}

Today, parallel to the increasing number and importance of psychosocial interventions in Alzheimer's disease, the importance is increasing. Although the disease cannot be cured completely, psychosocial interventions such as Music Therapy can slow down its course and contribute to the cognitive functions of the patients. In conclusion, there is a high level of evidence on the efficacy of music therapy in Alzheimer's patients and it provides important results showing the positive effects of music therapy in Alzheimer's patients. In centers that serve Alzheimer's patients, it may be suggested that music therapy environments can be created and psychiatric nurses who provide care to these patients should receive adequate training on this subject and actively practice Music therapy.

\section{References}

1. Alzheimer's Association (2018) Alzheimer's disease facts and figures. Alzheimer's \& Dementia 14: 367-429.

2. Öztürk MO, Uluşahin A (2008) Organik ruhsal bozukluklar (deliryum, bunama ve başka bilişsel bozukluklar). In: Öztürk MO, Uluşahin A, Ruh sağlığı ve bozuklukları II. ( $11^{\text {th }}$ edn), Ankara, Nobel Tıp Kitapevleri, 642-686.

3. Gurvit $\mathrm{H}$, Emre M, Tinaz S, Bilgic B, Hanagasi $\mathrm{H}$, et al (2008) The prevalence of dementia in an urban Turkish population. Am J Alzheimer Dis Other Demen 23: 67-76.

4. Aşiret GD, Kapucu S (2015) Alzheimer hastalarinin bilişsel ve davranişsal sorunlari üzerine etkili bir yöntem: Anımsama terapisi. Hacettepe Üniversitesi Hemşirelik Fakültesi Dergisi 2: 60-68.

5. Maviş İ, Özbabalık D (2006) Yaşılıkta nörolojik temelli iletişim sorunları ve dil ve konuşma terapisi. Sosyal Bilimler Dergisi 1: 1-17.

6. Barlas GÜ, Onan N (2008) Alzheimer hastası ve aileleri ile iletişim. Atatürk Üniversitesi Hemşirelik Yüksekokulu Dergisi 11: 105-111.

7. Livingston G, Johnston K, Katona C, Paton J, Lyketsos CG (2014) Systematic review of psychological approaches to the management of neuropsychiatric symptoms of dementia. Am J Psychiatry 162.

8. Gazes Y, Soldan A, Stern Y (2012) Alzheimer's disease. Elsevier Inc. 108-115.

9. Söylemez BA, Küçükgüçlü Ö (2017) Kognitif ve psikolojik sorunlar ve hemşirelik bakımı. In: Bilgili N, Kitiş Y, Yaşlılık ve yaşlı sağlığı. ( $1^{\text {st }}$ edn), Ankara, Vize Basın Yayın, 344367.

10. Akyar İ (2011) Demanslı hasta bakımı ve bakım modelleri. Hacettepe Üniversitesi Sağlık Bilimleri Fakültesi Hemşirelik Dergisi 18: 79-88.

11. Akpınar B, Küçükgüçlü Ö (2011) Demanslı bireylerin yaşam kalitesi ölçülebilir mi? Deuhyo Ed. 4: 141-143.

12. Takagi M (2012) Safety and neuroethical consideration of deep brain stimulation as psychiatric or dementia treatment. Asian Bioethics Review 4: 48-64.

13. Karamızrak N (2014) Ses ve müziğin organları iyileştirici etkisi. Koşuyolu Heart Journal 17: 54-57.

14. Lök N, Bademli K (2016) Alzheimer hastalarında müzik terapinin etkinliği: Sistematik derleme. Psikiyatride Güncel Yaklaşımlar 8: 266-274.

15. Boşnak M, Kurt AH, Yaman S (2017) Beynimizin müzik fizyolojisi. KSÜ Tip Fak Der 12: 35-44.

16. Fang R, Ye S, Huangfu J, Calimag DP (2017) Music therapy is a potential intervention for cognition of alzheimer's disease: A mini-review. Translational Neurodegeneration 6: $1-8$.

17. Roy C (2011) Research based on the Roy adaptation model: Last 25 years. Nurs Sci Q 24: 312-320.

18. Şişman FN, Kutlu $Y$ (2016) Yaşlılarda uyum güçlüğünü değerlendirme ölçeği'nin (yugdö) geliştirilmesi ve psikometrik özellikleri. Psikiyatri Hemşireliği Dergisi 7: 2533.

19. Flood M (2005) A Mid-range nursing theory of successful aging. TJTCT 9: 35-39.

20. Roy C (2009) The Roy adaptation model. ( $3^{\text {rd }}$ edn), Pearson Prentice Hall Health, New Jersey, 35-50.

21. Kydd P (2001) Using music therapy to help a client with alzheimer's disease adapt to long-term care. Am J Alzheimers Dis Other Demen 16: 103-108.

22. Guetin S, Portet F, Picot MC, Pommié C, Messaoudi M, et al. (2009) Effect of music therapy on anxiety and depression in patients with Alzheimer's type dementia: Randomised, controlled study. Dement Geriatr Cogn Disord 28: 36-46.

23. Raglio A, Bellelli G, Traficante D, Gianotti M, Ubezio MC, et al. (2008) Efficacy of music therapy in the treatment of behavioral and psychiatric symptoms of dementia. Alzheimer Dis Assoc Disord 22: 158-162.

24. Han HJ, Son SJ, Ha J, Lee JH, Kim S, et al. (2014) The effect of group musical therapy on depression and activities on daily living in patients with cognitive decline. Dement Neurocogn Disord 13: 107-111.

25. Suzuki M, Kanamori M, Watanabe M, Nagasawa S, Kojima E, et al. (2004) Behavioral and endocrinological evaluation of music therapy for elderly patients with dementia. Nurs Health Sci 6: 11-18.

26. Svansdottir HB, Snaedal J (2006) Music therapy in moderate and severe dementia of Alzheimer's type: A case-control study. Int Psychogeriatr 18: 613-621.

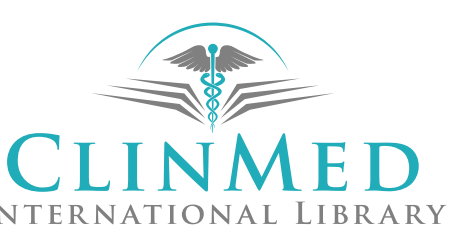

